\author{
DEPARTMENT OF THE INTERIOR \\ UNITED STATES GEOLOGICAL SURVEY
}

\title{
UNCONSOLIDATED MATERIALS, HARTFORD NORTH QUADRANGLE, CONNECTICUT
}

\author{
By \\ Fred Pessl, Jr., and C. T. Hildreth
}

FOLIO OF THE HARTFORD NORTH QUADRANGLE, CONNECTICUT MAP I-784 A 